\title{
REDAKTÖRENS FÖRORD: ERFARENHETER AV DELTAGANDE I POLITIK OCH SAMHÄLLE
}

\author{
Magnus Hagevi, Institutionen för statsvetenskap, Linnéuniversitetet \\ E-post I magnus.hagevi@1nu.se
}

Människor deltar i olika områden i samhället: utbildning, arbete, föreningsliv och politik. I två artiklar i detta nummer av SurveyJournalen studeras effekter utifrån olika erfarenheter av deltagande. I en artikel av Per Adman studeras hur erfarenheter inom utbildning, arbete, föreningsliv och politik är relaterad till tolerans. I en andra artikel redovisar Gissur Erlingsson och Richard Öhrvall en panelstudie om hur erfarenheten av att ha varit kommunalt förtroendevald inverkar på politiskt självförtroende och tillit. Att presentera dessa båda studier i detta nummer av SurveyJournalen är särskilt spännande då de utifrån tankar om vad som kan uppfattas som positiva effekter av deltagande kommer fram till delvis motsatta resultat.

(C) 2016 Magnus Hagevi. Detta är en Open Access artikel distribuerad under CC-BY-NC som innebär att du tillåter andra att använda, sprida, göra om, modifiera och bygga vidare på ditt verk, men inte att verket används i kommersiella sammanhang. http://dx.doi.org/10.15626/sj.20163100 